\begin{tabular}{|l|l|l||}
\hline \multicolumn{2}{|c|}{ PublisherInfo } \\
\hline \hline PublisherName & $:$ & BioMed Central \\
\hline \hline PublisherLocation & $:$ & London \\
\hline \hline PublisherImprintName & $:$ & BioMed Central \\
\hline \hline
\end{tabular}

\title{
Articles selected by Faculty of 1000: chemical modification analysis of siRNAs; allele-specific variation in gene expression; gut parasite comparative genomics; functional promoter variants; microRNA finction in leaf development
}

\begin{tabular}{|l|l|l||}
\hline \multicolumn{2}{|c|}{ ArticleInfo } \\
\hline \hline ArticleID & $:$ & 3474 \\
\hline \hline ArticleDOI & $:$ & $10.1186 /$ gb-2003-4-11-348 \\
\hline \hline ArticleCitationID & $:$ & 348 \\
\hline \hline ArticleSequenceNumber & $:$ & 18 \\
\hline \hline ArticleCategory & $:$ & Paper report \\
\hline ArticleFirstPage & $:$ & 1 \\
\hline \hline ArticleLastPage & $:$ & 3 \\
\hline \hline & $:$ & RegistrationDate : 2003-10-9 \\
ArticleHistory & $:$ & OnlineDate 2003-10-9 \\
\hline \hline
\end{tabular}




\begin{tabular}{|l|l|l||}
\hline ArticleCopyright & $:$ & BioMed Central Ltd2003 \\
\hline \hline ArticleGrants & $:$ & \\
\hline \hline ArticleContext & $:$ & 13059441111 \\
\hline
\end{tabular}

The Author(s)

\section{Summary}

A selection of evaluations from Faculty of $\mathbf{1 0 0 0}$ covering a chemical modification analysis of siRNAs; allele-specific variation in gene expression in the human genome; gut parasite comparative genomics; functional promoter variants; microRNA finction in leaf development.

\section{Chemical modification analysis of siRNAs}

siRNA function in RNAi: A chemical modification analysis. Chiu YL, Rana TM. RNA 2003, 9:1034-1048

For the Faculty of 1000 evaluation of this article please see: http://genomebiology.com/reports/F1000/ gb-2003-4-11-348.asp\#Chiu

\section{Allele-specific variation in gene expression}

Allelic variation in gene expression is common in the human genome. Lo $\mathrm{HS}$, Wang $\mathrm{Z}, \mathrm{Hu} \mathrm{Y}$, Yang HH, Gere S, Buetow KH, Lee MP. Genome Res 2003, 13:1855-1862.

For the Faculty of 1000 evaluation of this article please see: http://genomebiology.com/reports/F1000/ gb-2003-4-11-348.asp\#Lo

\section{Gut parasite comparative genomics}

Gene discovery in the Entamoeba invadens genome. Wang Z, Samuelson J, Clark CG, Eichinger D, Paul J, Van Dellen K, Hall N, Anderson I, Loftus B. Mol Biochem Parasitol 2003, 129:23-31. 
For the Faculty of 1000 evaluation of this article please see: http://genomebiology.com/reports/F1000/ gb-2003-4-11-348.asp\#Wang

\section{Functional promoter variants}

Functional analysis of human promoter polymorphisms. Hoogendoorn B, Coleman SL, Guy CA, Smith K, Bowen T, Buckland PR, O'Donovan MC. Hum Mol Genet 2003, 12:2249-2254.

For the Faculty of 1000 evaluation of this article please see: http://genomebiology.com/reports/F1000/ gb-2003-4-11-348.asp\#Hoogendoorn

\section{MicroRNA finction in leaf development}

Control of leaf morphogenesis by microRNAs. Palatnik JF, Allen E, Wu X, Schommer C, Schwab R, Carrington JC, Weigel D. Nature 2003, 425:257-263.

For the Faculty of 1000 evaluation of this article please see: http://genomebiology.com/reports/F1000/ gb-2003-4-11-348.asp\#Palatnik

This PDF file was created after publication. 